\title{
THE EFFECTIVENESS OF SELF-CARE MODEL ON DIABETES SELF- MANAGEMENT BEHAVIOUR
}

\author{
Dewi Prabawati ${ }^{1 *}$, Lia Natalia $^{2}$ \\ ${ }^{1,2}$ STIK Sint. Carolus, Jakarta \\ Email*: Deprab24@yahoo.com
}

\begin{abstract}
Introduction: The needs of diabetic patients are not only limited to adequate glycemic control but also correspond with preventing complications and increasing their awareness to participate in self-management. This study aimed to analyze the effectiveness self-care model to Diabetes self-management behaviour (DSM Behaviour) and Fasting Blood Glucose (FBG) levels. Methods: The study was conducted from June to August 2019 at Community Health Centers. This study employed a Quasi-Experimental pre-posttest with a control group design. There were 104 respondents obtained by purposive sampling technique, and assigned into experimental (52 respondents) and control group (52 respondents). FBG levels and DSM Behaviour were evaluated in the first and the seventh week using The Summary of Diabetes Self Care Activities (SDSCA) questionnaire. Results: Paired sample T-test statistical revealed a significant difference in decreasing levels on $F B G$ and increasing level of DSM Behaviour $(p<0.05)$ at before and after the intervention; Independent T-test discovered a significant difference on FBG and DSM Behaviour $(p<0.05)$ between the intervention and control group. The strongest effect as resulting from the parameter estimation model of SDSCA was a dimension of a healthy diet (2.96) followed by foot exercise (2.41) and activity (4.54). SDSCA showed marginal fit for FBG with $t$-value <2 and contribution determinant of $8.4 \%\left(R^{2}=0.084\right)$. Conclusions: Self-care model is an effective program that can improve DSM Behaviour and increase adequate glycemic control. In addition, this model needs to implement continuously to prevent complications and improve self-care to diabetic patients.
\end{abstract}

Keywords: blood glucose; diabetes; self-care model; self-management behaviour

\section{INTRODUCTION}

Diabetes has emerged as one of the world's biggest health problem, and the number of persons with diabetes is predicted to increase yearly. In Indonesia, the average occurrence of diabetes in the adult population is increased by age, and the highest risk age is between 65-74 years old. DKI Jakarta is the city which has the highest prevalence of diabetes diagnosed by a physician with $3.4 \%$; and its occurs in communities with higher education level (Riskesdas, 2018).

The needs of diabetic patients are not only limited to adequate glycemic control but also correspond with preventing complications and increasing their awareness to participate in selfmanagement. The chronicity of diabetes combined with its complications often cause discomfort feeling, such as tiresome that may lead to a feeling that they have lost control over their lives. Therefore the principle of self-care is applied, which hope to bring back this control to the individual, after empowering him/her with knowledge about the disease and how to manage diabetes (Kushwaha et al., 2016).

Self-care model was adopted from AADE (American Association of Diabetes Educators, 2014), which defined AADE7 self-care behaviours. AADE7 Self-care behaviours provide an evidence-based framework for the intervention of diabetes patient and it acts as a framework for patient-centred diabetes selfmanagement, which is oriented to the active participation of diabetes patients with goals to increase their knowledge and self-care management. There are seven essential components of self-care behaviours which predict good outcomes, namely healthy eating, being physically active, monitoring, compliance with medications, good problem solving, healthy coping and risk-reducing behaviours (Sukartini et al., 2020).

Furthermore, it is explained that these seven self-care behaviours have been found to facilitate the development of knowledge, have a positive correlation with good glycemic control, 
reduction of complications and improvement in the quality of life (ADA, 2015; Shrivastava et al., 2013). Patients with diabetes are motivated to engage in diabetes self-care by following a complex set of behavioural actions to care for their disease. Some actions are expected can increase knowledge and awareness to perform healthy lifestyle with support from a health professional team to improve the quality of life on patients with diabetes (Eva et al., 2018).

American Diabetes Association (ADA, 2015) highlighted the importance of diabetes patients should care on treatment training they attend, and need to adopt changes in their lifestyle to delay its relevant complications. Zareban et al., (2014) performed a study on the impact of self-care training instruction to 138 female patients with type 2 diabetes, and they found out that level of knowledge, attitude and self-care scores increased significantly after three months follow-up session.

A program provided by National health Department, called Program Pengelolaan Penyakit Kronis (PROLANIS), has become a government's health care program which implemented with a proactive approach and targeted for chronic diseases (BPJS, 2014). However, health activities run by community health centre for diabetes patients were not following seven components of self-care yet, thus it may cause less understanding and awareness of the disease. Therefore, this study aims to analyze the effectiveness of self-care model to DSM Behaviour and glycemic control through fasting blood glucose level.

\section{METHODS}

This was quasi-experimental, pretestposttest and control group design. The study was conducted from June to August 2019 at community health centres, Central Jakarta. The sample size was calculated using compare two means formula referring to mean and standard deviation of the previous study of Ernawati et al., (2015). In this study, non-probability method, purposive sampling technique was applied, and there were 104 diabetes patients met the inclusion and exclusion criteria. The inclusion criteria such as aged between $35-75$ years old live with family, able to perform physical activity, while the exclusion criteria were respondents with walking disability, have a history of stroke and develop diabetes ulcer. The respondents were assigned to the control group (52 respondents) and intervention group (52 respondents). The intervention group received 7 weeks self-care model, such as health education classes to identify diabetes disease and emphases the importance of consuming healthy food and perform physical activity, demonstration on reading and understanding food label, and stress management and perform diabetes exercise in a group, as recommended by Persatuan Diabetes Indonesia (Persadia).

Research data were collected over seven weeks days using datasheet for the demographic profile of the respondents. Calibrated blood glucose meter with stick strips (Autocheck series AI01003077) was utilized to measure fasting blood glucose level, and The Summary of Diabetes Self Care Activities/SDSCA questionnaire was used to measure DSM Behaviour. SDSCA questionnaire is a self-reported questionnaire that assesses the frequency of performing diabetes self-care in the preceding 7 days. The respondents score their adherence to the selfcare activities within the past week, ranging from 0 to 7 days, where higher score presents better self-care. The SDSCA has been proven to have good psychometric properties, with acceptable inter-item correlation ( mean $=0.47$ ), moderate test-retest correlations (mean $=0.40$ ), and low correlations among the five dimensions (mean $r=0.23$ ) (Toobert Deborah J., Hampson, Sarah S., Glasgow, 2000).

The study was approved by the Sint Carolus School of Health Sciences ethics committee (No. 022/KEPPKSTIKSC/IV/2019). Paired sample T-Test was used to determine whether there are statistically significant differences before and after the intervention, while Independent T-test was done to find the significant difference between the groups of 
study. Multivariate analysis was applied to determine the effect of DSM Behaviour's dimension of fasting blood glucose.

\section{RESULTS}

Table 1 showed the frequency and percentage distribution of the participant. Most of the respondents in both groups were age between 45-59 years old, female, graduated from basic education and have a duration of illness $>1$ year.

Table 1. Frequency and percentage distribution of the respondents

\begin{tabular}{lcccc}
\hline \multirow{2}{*}{ Characteristics } & \multicolumn{2}{c}{ Intervention $(\mathrm{n}=52)$} & \multicolumn{2}{c}{ Control $(\mathrm{n}=52)$} \\
\cline { 2 - 5 } & $\mathrm{n}$ & $\%$ & $\mathrm{n}$ & $\%$ \\
\hline Age & 2 & 3.8 & 4 & 6.9 \\
$<45$ years old & 28 & 53.8 & 29 & 50 \\
$45-59$ years old & 22 & 42.3 & 25 & 43.1 \\
$\geq 60$ years old & & & & \\
Gender & 44 & 84.6 & 42 & 72.4 \\
Female & 8 & 15.4 & 16 & 27.6 \\
Male & & & & \\
Educational Background & 35 & 67.3 & 30 & 51.7 \\
Basic & 17 & 32.7 & 28 & 48.3 \\
Advance & & & & \\
Duration of illness & 12 & 23.1 & 21 & 36.2 \\
$<1$ years & 40 & 76.9 & 37 & 63.8 \\
$>1$ years & & &
\end{tabular}

Table 2 presents the difference in the mean score of DSM Behaviour and FBG. There were significant within the group differences in DSM behaviour and FBG before and after the intervention of the self-care model $(\mathrm{p}<0.05)$.

Table 2. The mean and significant difference within and between the groups

\begin{tabular}{|c|c|c|c|c|c|c|}
\hline \multirow{3}{*}{ Variables } & \multicolumn{3}{|c|}{ Paired T-Test } & \multicolumn{3}{|c|}{ Independent T-Test } \\
\hline & \multicolumn{2}{|c|}{ Mean } & \multirow{2}{*}{ pvalue } & \multicolumn{2}{|c|}{ Mean } & \multirow{2}{*}{ pvalue } \\
\hline & Before & After & & Intervention & Control & \\
\hline DSM Behaviour & 3.29 & 4.67 & 0.001 & 4.67 & 3.67 & 0.000 \\
\hline Healthy Diet & 4.07 & 4.96 & 0.001 & 4.96 & 4.53 & 0.246 \\
\hline Exercise & 3.34 & 5.19 & 0.000 & 5.19 & 3.93 & 0.550 \\
\hline Blood Sugar Testing & 0.84 & 1.59 & 0.003 & 1.59 & 1.16 & 0.990 \\
\hline Foot Care & 2.63 & 5.23 & 0.000 & 5.23 & 3.84 & 0.005 \\
\hline Medication & 6.09 & 6.63 & 0.020 & 6.63 & 3.46 & 0.000 \\
\hline Smoking & 0.58 & 0.96 & 0.322 & 0.96 & 0.96 & 1.000 \\
\hline Fasting Blood Glucose & 170.38 & 137.81 & 0.000 & 137.81 & 146.48 & 0.017 \\
\hline
\end{tabular}

In addition, there was a significant difference in all DSM behaviour's dimensions, except for smoking ( $>0.05)$. There is an increase of mean score in all dimensions of DSM behaviour, where exercise increase from 3.34 to 5.19 (1.779) and foot care from 2.63 to
5.23 (2.615); these variables have the highest increase mean score after the intervention of self-care model. Moreover, there were significant between-group differences in DSM Behaviour and FBG for intervention and control group $(\mathrm{p}<0.05)$; however, only 
dimensions of foot care and medication shows $\quad(\mathrm{p}<0.05)$. a significant difference between the group

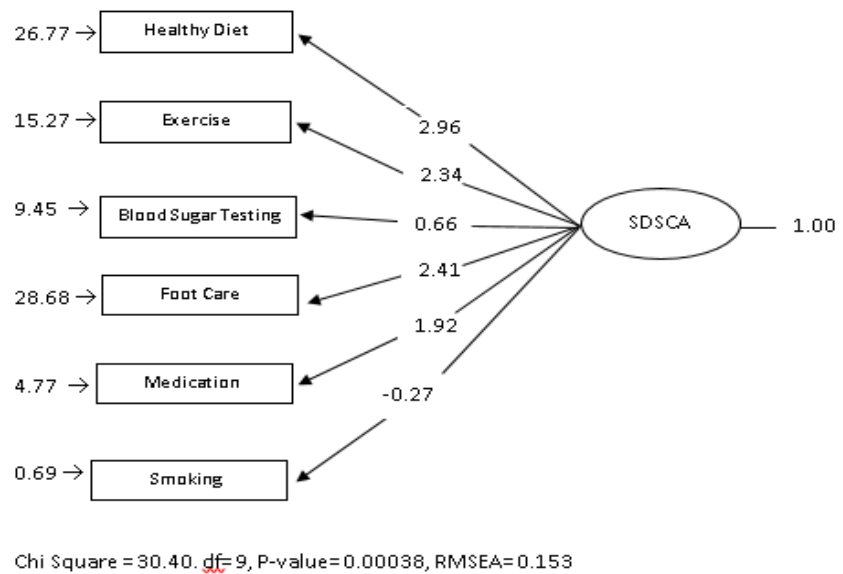

Figure 1. Parameter estimation of SDSCA

Figure 1 presents parameter estimation of SDSCA's dimension, where the dimension of healthy eating has the strongest effect with the value of 2.96 , followed by the dimension of foot care (2.41), exercise (2.34) and medication (1.92).

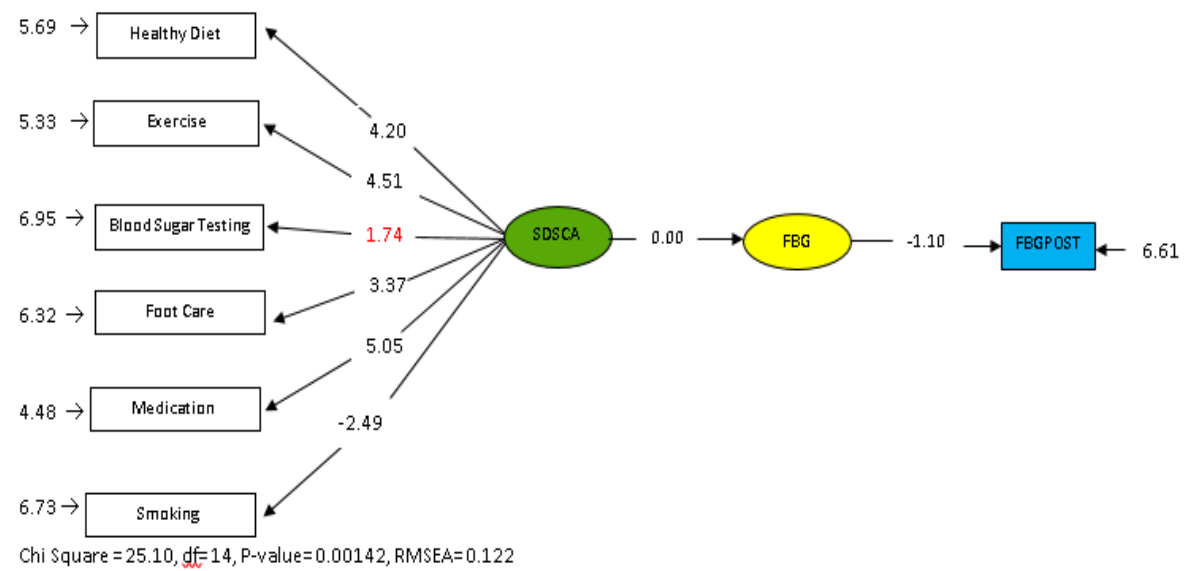

Figure 2. Structural equation model of DSM Behaviour as measured by SDSCA to FBG

Figure 2 shows the Structural equation model effect of DSM behaviour to FBG. The model shows a marginal fit for FBG with $t$ value $<2$, it means that SDSCA can predict FBG with contribution determinant $8.4 \%\left(\mathrm{R}^{2}=\right.$ $0.084)$. The highest determinant contribution of SDSCA is medication $39 \%\left(\mathrm{R}^{2}=0.39\right)$, followed by exercise $29 \%\left(\mathrm{R}^{2}=0.29\right)$, and healthy diet $23 \%\left(\mathrm{R}^{2}=0.23\right)$.

\section{DISCUSSIONS}

The finding of this study is in line with a theory that diabetes is a chronic disease which affects individuals throughout the life and it occurs more frequently in individuals in the ages over 30 years old (Lewis, 2014). According to (Ekpenyong et al., 2012), the insulin resistance will be worse along with the growth of ages, so the prevalence of diabetes increases with the growth of the ages.

Women are affected by diabetes risk because physically, they have a greater chance of the increasing BMI than men thus it can 
decrease the insulin sensitivity's response, moreover, women have worse control of blood glucose levels than men (Astuti \& Setiarini, 2013). Taylor (2010) states that a large number of women who have type 2 diabetes, caused by the decrease of estrogen hormones, especially when they are menopause because of estrogen and progesterone hormones able to enhance the insulin response in the blood.

Self-management has been applied extensively with the greatest success. Dimensions of DSM behaviour have been tested and have a positive correlation with the good glycemic index, decrease of complications, and improve quality of life (Shiravastava, Shiravastava \& Ramasay, 2013). By conducting self-care, diabetes patients will modify healthy lifestyle and diet properly, supported by health care workers to increase behavioural changes.

WHO highlighted the importance of performing health education; it is expected that diabetes patients with a high level of knowledge will have a better understanding of the disease and have a better impact on conducting self-care management effectively, hence, be able to prevent complications. ADA (Funnell et al., 2008) explains that there was a four-fold increase in diabetic complications for diabetes patients who had not received health education related to self-care practices.

Self-care model is a program aimed to modify the lifestyle of diabetes patients by combining seven components behaviour as recommended by the American Association of Diabetes Educators (2014). This is an innovation program because in general, the intervention of diabetes patients only refers to 5 pillars diabetes (PERKENI, 2015). This program provides health education to increase patients' knowledge about diabetes in general, healthy diet, physical activity, medication, blood sugar monitoring, problem-solving to prevent hypo/hyperglycemia, stress management, reducing risk behaviour to prevent complication such as foot care, stop smoking and monitoring physiologic parameters. By implementing self-care model,

it is expected diabetes patients be able to identify barriers, enhance problem-solving, increase awareness and skills to practice a healthy lifestyle to achieve a better and productive life.

The result of the parameter estimation of SDSCA showed that dimension of a healthy diet has the strongest effect after the self-care model (2.96) followed by foot exercise (2.41) and activity (4.54). The intervention of Selfcare model emphasized dietary intake program by giving health education on healthy eating of $3 \mathrm{~J}$ (variety, quantity and schedule), reading a food label and avoiding high glycemic food. Related to physical activity, respondents were given a pedometer to stimulate them to walk for 30 minutes daily; moreover, some respondents stated they attend the sessions regularly because they pleased to perform diabetes gymnastics in a group before class.

Regarding the determination of contribution, it was explained that medication dimension is effective for those who were not compliance on healthy eating and exercise in daily life. Insulin decrease blood glucose after meal through uptake and utilization glucose at muscle, fat and liver cell (Hinkle \& Cheever, 2014). Healthy eating will stabilize blood glucose and lipid on the normal range. Physical activity controls blood sugar level by increasing the glucose taking my body muscular and improving the use of insulin.

Issues that need to be improved in the behaviour of diabetes management is monitoring blood sugar and smoking behaviour. Most of the respondents (73.1\%) do not check their blood sugar in a week. Monitoring of blood sugar levels only conducted by respondents who have high socioeconomic status. Monitoring of the blood sugar decrease time to time because the lack of the health professional's adequacy to explain how to read the parameter of the blood sugar and lack of education on appropriate responses after reading blood sugar test (Peel et al., 2007).

\section{CONCLUSIONS}


Self-care model is an effective program to modify self-care behaviour and to control glycemic control. There are significant differences in DSM Behaviour and blood sugar levels in diabetes patients after following the intervention of the self-care model. The program brings a strong effect, especially to improve the behaviour of healthy eating, perform foot care and exercise. This research recommends the need for applying self-care model sustainably to prevent complications and improve the self-care of diabetes patients.

\section{ACKNOWLEDGEMENT}

This work was supported by The Association of Indonesian Nurse Education Center (AINEC) under AINEC research award 2019; therefore, researchers would like to express gratitude to AINIC for financial support during the study. We also thank Community health Centers, Central Jakarta for all of the facilities and support that have been given throughout data collection.

\section{REFERENCES}

ADA. (2015). Standards of medical care in diabetes - 2015 abridged for primary care providers. Clinical Diabetes, 33(2), 97111.

https://doi.org/10.2337/diaclin.33.2.97

American Association of Diabetes Educators. (2014). AADE7 Selfcare behaviours. The Diabetes Educator, 1-11. https://doi.org/10.4324/9781315853178

Astuti, C. M., \& Setiarini, A. (2013). FaktorFaktor yang Berhubungan dengan Pengendalian Kadar Glukosa Darah Pasien Diabetes Melitus Tipe 2 Rawat Jalan di Poliklinik Penyakit Dalam RSJ Prof.Dr.Soerojo Magelang Tahun 2013. Program Studi Gizi, Fakultas Kesehatan Masyarakat, Universitas Indonesia.

BPJS. (2014). Panduan praktis Prolanis (Program pengelolaan penyakit kronis). BPJS Kesehatan.

Ekpenyong, C. E., Akpan, U. P., Ibu, J. O., \&
Nyebuk, D. E. (2012). Gender And Age Specific Prevalence And Associated Risk Factors of Type 2 Diabetes Mellitus In Uyo Metropolis, South Eastern Nigeria. Diabetologia Croatica, 41(1), 17-28.

Ernawati, N., Suharto, \& Dewi, Y. S. (2015). Pemberdayaan Pasien Berbasis Experiental Learning Terhadap Perilaku Pencegahan Komplikasi Akut dan Kadar Glukosa Darah Pasien DM. Jurnal Ners, 10(2), 256-264. https://doi.org/http://dx.doi.org/10.20473/j n.V10I22015.256-264

Eva, J. J., Kassab, Y. W., Neoh, C. F., Ming, L. C., Wong, Y. Y., Hameed, M. A., Hong, Y. H., \& Moklesur Rahman Sarker, M. (2018). Self-care and self-management among adolescent T2DM patients: A review. Frontiers in Endocrinology, 9(OCT), 1-7. https://doi.org/10.3389/fendo.2018.00489

Funnell, M. M., Brown, T. L., Childs, B. P., Haas, L. B., Hosey, G. M., Jensen, B., Maryniuk, M., Peyrot, M., Piette, J. D., Reader, D., Siminerio, L. M., Weinger, K., \& Weiss, M. A. (2008). National standards for diabetes self-management education. Diabetes Care, 31(SUPPL. 1). https://doi.org/10.2337/dc08-S097

Kushwaha, A., Kumari, S., \& Kushwaha, N. (2016). Self care in diabetes: a study amongst diabetics in an urban community. International Journal of Community Medicine and Public Health, 3(1), 293$298 . \quad$ https://doi.org/10.18203/23946040.ijcmph20151579

Peel, E., Douglas, M., \& Lawton, J. (2007). Self monitoring of blood glucose in type 2 diabetes: Longitudinal qualitative study of patients' perspectives. British Medical Journal, 335(7618), 493-496. https://doi.org/10.1136/bmj.39302.444572 .DE

PERKENI. (2015). Konsensus Pengelolaan dan Pencegahan Diabetes Melitus tipe 2 di Indonesia 2015. In Pengurus Besar Perkumpulan Endokrinologi Indonesia (PB Perkeni) (Vol. 1). 
https://doi.org/10.1017/CBO97811074153 24.004

Riskesdas. (2018). Hasil Utama Riskesdas 2018.

Shrivastava, S. R., Shrivastava, P. S., \& Ramasamy, J. (2013). Role of self-care in management of diabetes mellitus. 12(1), 1. https://doi.org/10.1186/2251-6581-12-14

Sukartini, T., Theresia Dee, T. M., Probowati, R., \& Arifin, H. (2020). Behaviour model for diabetic ulcer prevention. Journal of Diabetes and Metabolic Disorders. https://doi.org/10.1007/s40200-019-
00484-1

Toobert Deborah J., Hampson, Sarah S., Glasgow, R. (2000). The Summary of Diabetes Self-Care Activities Measure. Diabetes Care, 23(July).

Zareban, I., Niknami, S., Hidarnia, A., Rakhshani, F., Shamsi, M., \& Karimy, M. (2014). Effective intervention of self-care on glycaemia control in patients with type 2 diabetes. Iranian Red Crescent Medical Journal, 16(12). https://doi.org/10.5812/ircmj.8311 